\title{
Sedimentary recycling, provenance and paleoweathering from chemistry and mineralogy of Mesozoic continental redbed mudrocks, Peloritani mountains, southern Italy
}

\author{
Giovanni Mongelli, ${ }^{1 *}$ Salvatore Critelli ${ }^{2}$ Francesco Perri,${ }^{1}$ Maurizio Sonnino ${ }^{2}$ and Vincenzo Perrone ${ }^{3}$ \\ ${ }^{1}$ Dipartimento di Scienze Geologiche, Università degli Studi della Basilicata, Campus di Macchia Romana, 85100 Potenza, Italy \\ ${ }^{2}$ Dipartimento di Scienze della Terra, Università degli Studi della Calabria, 87036 Arcavacata di Rende (CS), Italy \\ ${ }^{3}$ Istituto di Geologia, Universià degli Studi di Urbino, loc. Crocicchia, 61029 Urbino, Italy
}

(Received May 25, 2005; Accepted September 28, 2005)

\begin{abstract}
The Triassic to Lowermost Jurassic mudrocks from continental redbeds of the Longi-Taormina Unit (Calabria-Peloritani Arc; southern Italy) have been mineralogically, chemically and petrographically analyzed, in order to reveal their complex history, which record an important phase of the geological evolution of the Mediterranean area.

The Late Triassic corresponds with a low first-order sea level stand and a time of high continental emergence whereas the Early Jurassic was the time of the initiation of the first-order sea level rise in the mid-Mesozoic, generally marked by a transgressive trend.

The mineralogical assemblage, dominated by the occurrence of illite and illite/smectite mixed layers, coupled to the CIA index and to the A-CN-K plot, indicates post-depositional K-enrichments.

Palaeoweathering indices (CIW and PIA ratios) suggest that the source experienced intense weathering and that they likely record a recycling effect from their metasedimentary basement rocks. A recycling effect is also suggested by the distribution of $\mathrm{Al}_{2} \mathrm{O}_{3}, \mathrm{TiO}_{2}$, and $\mathrm{Zr}$. In the $\mathrm{Zr} / \mathrm{Sc}$ vs. the $\mathrm{Th} / \mathrm{Sc}$ plot the redbeds are not clustered along the primary compositional trend but fall along a trend involving zircon addition and thus sediment recycling. Recycling could significantly affect the weathering indices which likely monitor a cumulative effect including a first cycle of weathering at the source rocks. Weathering occurred under hot, episodically humid climate with a prolonged dry season. Wet-humid conditions favored the formation of stream channels that eroded the soil profiles, whereas the dry season promoted the sedimentation. The climate alternation in the Early Jurassic favored recycling.

An additional provenance terrane occurring in the basement, including metavolcanic rocks having mafic composition cannot be excluded, since the Eu anomaly is slightly higher than the PAAS value. Although the effects of recycling on $\mathrm{REE}$ distribution are uncertain, the $\mathrm{Eu} / \mathrm{Eu}^{*}$ should increase, as more feldspar is destroyed during weathering and diagenesis. This involves that the $\mathrm{Eu} / \mathrm{Eu}^{*}$ ratio could monitor a supply of low $\mathrm{Eu} / \mathrm{Eu} *$ mafic detritus which compensate for the recycling effect by reducing Eu/Eu*. Eu released during the dissolution of feldspar could be retained by clay minerals contributing to minimize the recycling induced increase of the Eu-anomaly. This may involve that the recycling effect on the Euanomaly was minor and that the low $\mathrm{Eu} / \mathrm{Eu}$ * mafic detritus supply was also minor. The subordinate importance of a mafic supply is confirmed also by other provenance proxies including the La-Th-Sc plot and the $\mathrm{Cr} / \mathrm{V}$ and $\mathrm{Y} / \mathrm{Ni}$ ratios.

The proportions of illitic layers in I/S mixed layers coupled with the illite crystallinity values, expressed as Kübler Index (KI), suggesting an estimated temperature experienced by the Longi Units in the range of $100-150^{\circ} \mathrm{C}$. Starting from this range the diagenetic/tectonic evolution should correspond to a lithostatic/tectonic loading of about 4-5 km.
\end{abstract}

Keywords: mudrocks, paleoweathering, recycling, provenance, Mesozoic continental redbeds, southern Italy

\section{INTRODUCTION}

The chemical composition of sedimentary rocks is an important record of the geological evolution of the continental crust through time because some elements are quantitatively transported in the terrigeneous fine fraction of

\footnotetext{
*Corresponding author (e-mail: mongelli@unibas.it)

Copyright (c) 2006 by The Geochemical Society of Japan.
}

a sediment (Taylor and McLennan, 1985). Of these, the rare earth elements (REE), Th, and Sc are the most useful because their distribution is not affected by secondary processes. The REE pattern of fine-grained siliciclastic sediments and some elemental ratios, especially $\mathrm{Eu} / \mathrm{Eu}^{*}$, are assumed to reflect the exposed crustal abundances in the source area (McLennann et al., 1993; Mongelli, G. et al., 1996; Fedo et al., 1996; Hassan et al., 1999; Bauluz et al., 2000; Cullers, 2000; Condie et al., 2001; Mongelli, 2004, among others). On the contrary, mobile elements 


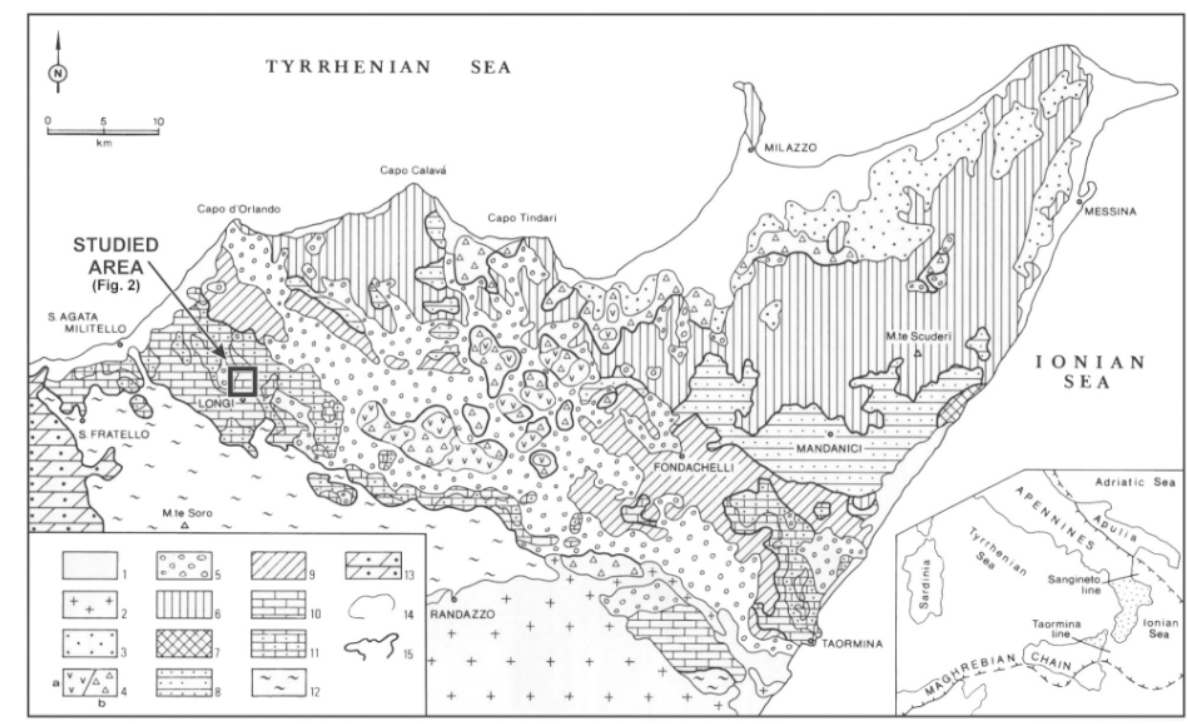

Fig. 1. Geological sketch of the Peloritani Mountains. 1: Recent to Upper Pliocene dominantly clastic deposits; 2: Etna volcanics; 3: Lower Pliocene-Upper Tortonian mostly clastic deposits; 4: Floresta Calcarenites (a; Langhian) and variegated shales of the “Antisicilide Complex" (b; Paleogene-Cretaceous); 5: Stilo-Capo d'Orlando Formation (Lower Miocene), 6: Aspromonte and Mela Units (Pre-Triassic); 7: Mandanici Unit (Cretaceous-Paleozoic); 8: Ali Unit (Cretaceous-Upper Paleozoic); 9: Fondachelli Unit (Cretaceous-Paleozoic); 10: Longi-Taormina Unit sedimentary cover (Aquitanian-Upper Triassic); 11: Longi-Taormina Unit basement (Paleozoic); Maghrebian Chain-12: Sicilide Units (Monte Soro and Troina-Tusa; Lower Miocene-Cretaceous); 13: External Units (Panormide and Imerese; Middle Miocene-Middle Triassic); 14: Stratigraphic contacts; 15: Tectonic contacts. Modified after de Capoa et al. (1997).

(such as $\mathrm{Na}$ and $\mathrm{Ca}$ ) can be used to evaluate the degree of chemical weathering, characterizing paleoclimates in source regions at the time of deposition (Nesbitt and Young, 1982). Further the mineralogical features of finegrained siliciclastic sediments proved to be a useful record of possible post-depositional changes, including diagenesis and incipient metamorphism (Chamley, 1995).

In the Alpine orogenic belts, developed along the central-western Mediterranean region from the Betic Cordilleras to Apenninic Chain, clastic sediments preserve informations of the Mesozoic Pangea supercontinent break-up, the Tethyan Ocean rifting and its closure during Tertiary orogenesis. The interpretations of the history of these sediments can be used to test paleogeographic and paleotectonic reconstructions during the key orogenic phases (Critelli, 1999) and can be of relevance for evaluating global changes (Perrone et al., 2005). The continental rift-valley phase and the proto-oceanic phase of the Tethyan rifting in the western-central Mediterranean region occurred during the Late Triassic to Early Jurassic, and in many tectonic units of the Alpine orogenic belts, continental redbeds, which mark the base of the MesoCenozoic covers, are interpreted as deposited during the rift-valley phase. The domain of these redbeds was located around small mountain areas, from which alluvial depositional systems provided siliciclastic supply to neighbouring nascent continental sedimentary basins formed during Triassic rifting. They reveal the erosion of metamorphosed Paleozoic successions extensively intruded by felsic plutonic rocks. Chemical weathering of such rocks under tropical, hot and episodically humid climate with a prolonged dry season allowed oxidation of iron and rubefaction of soils and sediments and caused illitization of silicate minerals and concentration of quartz in thick soil profiles. These soils were later denudated by fluvial erosion, producing relatively mature, quartz-rich red deposits (Perrone et al., 2005).

In this paper we clear up the complex history of a set of redbed samples from a selected section of Upper Triassic to Lower Jurassic continental redbeds (Longi section, Peloritani Mountains), using geochemical and mineralogical tools. The history of these sediments, which include source area weathering, provenance, recycling and burial, record an important phase of the geological evolution of the Mediterranean area.

\section{Geological AND Stratigraphic Settings}

The Calabria-Peloritani Arc represents an arcuate orogenic sector connecting the NW-SE-trending Southern Apennines with the E-W-trending Sicilian Maghrebids (Bonardi et al., 2001 and references therein). It is made up both of units involving pre-Alpine crystalline basement and ophiolitic units, some of them evidencing HP/ 


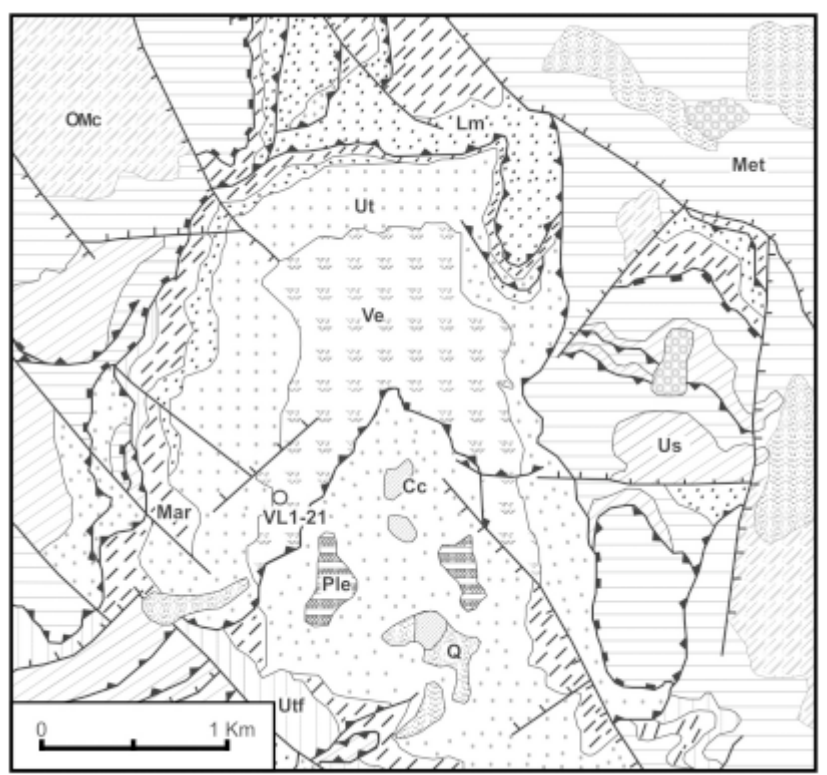

Fig. 2. Geological sketch map of Longi area and location of the studied samples (VL1-VL19). Q: Brecce di versante, alluvial deposits, landslides (Holocene-Pleistocene); OMc: StiloCapo d'Orlando Formation (Middle-Upper Burdigalian); San Marco d'Alunzio Imbricate: $U s=$ Platform and pelagic limestones (Liassic-Malm); Met $=$ metapelites and metarenites (Palaeozoic); Longi Imbricate: Utf = Sandy-pelitic turbidites (Aquitanian); Mar: "Scaglia"-like marls and marly limestones (Upper Oligocene-Upper Cretaceous) and "Maiolica"-like limestones (Lower Cretaceous-Tithonian); Lm = marly limestones and marls (Middle Liassic); Ut = Neritic limestones and dolostones (Lower Liassic); Ve = continental redbeds (Pseudoverrucano-like conglomerates, sandstones and pelites; Lower Liassic-Upper Triassic). Line with triangles = Thrust and reverse fault; Line with squares $=$ Overthrust. Modified after Lentini et al. (2000).

LT metamorphism and a pre-Miocene tectonism.

The Peloritani Mountains represent the southwestern extremity of the Calabria-Peloritani Arc and constitute an orogenic sector in which many tectonic units of the Alpine nappe stack are exposed. The Peloritanian nappes have been piled as from early Miocene and thrusted, during the Middle Miocene (Lentini and Vezzani, 1975) onto the nappes originated from the Maghrebian Flysch Basin, these latter made up of Upper Jurassic-middle Miocene sedimentary terrains and cropping out in the Nebrodi and Madonie Mountains. The tectonic boundary between Peloritanian and Flysch Basin nappes is known as "Taormina line" (Scandone et al., 1974).

Some Peloritanian nappes (Fig. 1) consist only of preAlpine crystalline basement (Mela and Aspromonte Units), others include also a Meso-Cenozoic cover (LongiTaormina, Fondachelli, Mandanici, Piraino and Alì Units). The Longi-Taormina Unit, cropping out along a WNW-

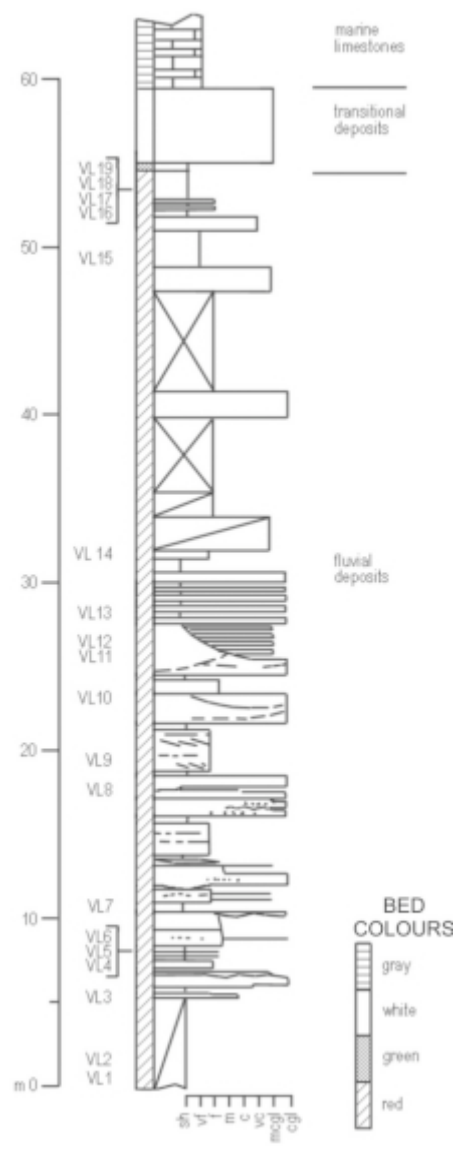

Fig. 3. Sedimentologic column of the continental redbeds (Verrucano Auct.) at the Longi section, Peloritani Mountains, Sicily. VL1 to VL19 mudrock samples used for mineralogic and geochemical analyses.

ESE oriented belt, $10 \mathrm{~km}$ wide and $70 \mathrm{~km}$ long, constitutes the lowermost nappe in the Peloritanian nappe stack and is arranged in three imbricated subunits. It shows thick pre-Alpine crystalline basements and the most extensive and complete Mesozoic to Cenozoic sedimentary cover of the whole Calabria-Peloritani Arc. The basements of the three imbricates consist of low-grade metamorphics (phyllite, metarenite, metalimestone and metavolcanic rocks) of Paleozoic age (Messina et al., 1996, among others), on which sedimentary successions, rest unconformably (Lentini, 1975; Lentini and Vezzani, 1975; Bonardi et al., 1976). The redbeds forming the base of the successions, in particular, have variable thickness from few metres to over 200 metres.

The Longi Imbricate (Arnone et al., 1978), cropping out on the Tyrrhenian versant of the Peloritani Mountains (Fig. 1) represents the largest subunit on the LongiTaormina Nappe.

In the Longi Imbricate the continental redbeds are particularly thick (over $200 \mathrm{~m}$ ), whereas they are few 
metres in the other subunits. In particular, in the Longi section, cropping out immediately NW of the homonimous village (Fig. 2), Upper Triassic lenticular conglomerate and sandstone strata, representing fluvial channel-fill, interbedded with thin layers of red clays, are well exposed.

The measured stratigraphic section is about $60 \mathrm{~m}$ thick (Fig. 3). In the outcrop the contact between the metamorphic basements and the sedimentary successions is not visible, and many little faults are present, especially in transition to limestones. The fluvial deposits are characterized by sandstone and conglomerate beds, thick between 10 and $300 \mathrm{~cm}$, interbedded with centimetrical layers of mudrocks; however the base of studied section shows some meters of covered clays. The sandstone beds are often lenticular in 5-10 meters, and normally the beds show an erosional base, very coarse or microconglomeratic; internally levels of pebbles (size 2$7 \mathrm{~cm}$ ) are frequently present, as well as cross and curved laminae. In the medium of measured section an erosion of two meters is filled by planar thin beds. Even if the correlation with other outcrops is not possible, the studied section can be interpreted as a portion of braided river, a very little outcrop (likely in landslide) near Longi village shows a thin sequence of mudrocks with thin planar and parallel sandstone beds, interpreted as floodplain deposits.

\section{SAMPLing AND MethodS}

Nineteen mudrock samples, interbedded in the quartzarenite and conglomerate strata, were collected along the Longi section. The mineralogy of clay fractions $(<2 \mu \mathrm{m})$ has been obtained by XRD using a Siemens D5000 ( $\mathrm{CuK} \alpha$ radiation, graphite secondary monochromator, sample spinner). In order to distinguish chlorite from kaolinite, the samples have been heated to $550^{\circ} \mathrm{C}$ for one hour. The heating causes that the intensity of the chlorite 001 reflection increases greatly and shifts to about 6.3 to $6.4^{\circ} 2 \theta$ whereas kaolinite becomes amorphous to $\mathrm{X}$-ray and its diffraction pattern disappears (Moore and Reynolds, 1997).

In order to determine the degree of post-sedimentary processes possibly affecting the samples analysed in the present study and the range of temperature they experienced, the most widely XRD-based illite "crystallinity" technique (Merriman and Peacor, 1999) was used. The most widely adopted method for measuring 10 - $\AA$ peak profile is still the one first used by Kübler (1967); the Kübler Index (KI) measured the width of the 10 - $\AA$ peak at half-height above the background (FWHM). Illite "crystallinity" values (IC), expressed as Kübler Index (KI), and $\%$ of illitic layers in I/S mixed layers were measured in the pelite samples as indicators of diagenesis and lowgrade metamorphism (Pollastro, 1993) and to estimate tectonic loading (stress) experienced by the Early Jurassic continental redbeds.

The illite crystallinity index, expressed as Kübler Index (KI), was measured on both air-dried and ethyleneglycol solvated slides; ethylene-glicol (EG) treatment was carried out on some samples to corroborate the identification of smectite and/or illite-smectite mixed-layers. Our IC measurements $(y)$ were transformed into C.I.S. values $(x)$ according to the equation $y=1.8957 x+0.0104\left(R^{2}=\right.$ $0.9817)$, obtained in laboratory using the international standards of Warr and Rice (1994).

Elemental analyses for major and some trace elements ( $\mathrm{Nb}, \mathrm{Zr}, \mathrm{Y}, \mathrm{Sr}, \mathrm{Rb}, \mathrm{Ba}, \mathrm{Ni}, \mathrm{Co}, \mathrm{Cr}, \mathrm{V}$ ) concentrations were obtained by X-ray fluorescence spectrometry (Philips PW 1480) on pressed powder disks. X-ray counts were converted into concentrations by a computer program based on the matrix correction method according to Franzini et al. (1972, 1975) and Leoni and Saitta (1976). Average errors for trace elements are less than $\pm 5 \%$ except for those elements at $10 \mathrm{ppm}$ and lower $( \pm 5-10 \%)$.

Total loss on ignition (L.O.I.) was determined, after heating the samples for three hours, at $900^{\circ} \mathrm{C}$.

Instrumental Neutron Activation Analysis (INAA) at the Activation Laboratories (Ancaster, Canada) was used to determine the abundance of the rare earth elements ( $\mathrm{La}$, $\mathrm{Ce}, \mathrm{Nd}, \mathrm{Sm}, \mathrm{Eu}, \mathrm{Tb}, \mathrm{Yb}$ and $\mathrm{Lu}$ ) and $\mathrm{Sc}, \mathrm{Zn}, \mathrm{Cs}$, Th, and U. Average errors for trace elements are less than $\pm 5 \%$ except for those elements at $10 \mathrm{ppm}$ and lower ( $\pm 5-10 \%)$. The estimated precision and accuracy for trace element determinations are better than 5\%, except for those elements having a concentration of $10 \mathrm{ppm}$ and lower (10$15 \%)$.

\section{Mineralogy}

The samples are mainly composed of clay minerals (illite, illite/smectite mixed layers and negligible amounts of kaolinite and chlorite), quartz, hematite and negligible amounts of feldspars. The $<2 \mu \mathrm{m}$ grain-size fraction is composed by illite prevailing on illite/smectite mixed layers and negligible amounts of kaolinite and chlorite.

The Kübler Index (KI) values for the samples studied, range between $0.66^{\circ}$ and $0.72^{\circ} \Delta 2 \theta$; even if there are little difference, the mean illite crystallinity value for the pelitic sediments of the stratigraphic section studied is $0.70^{\circ} \Delta 2 \theta\left( \pm 0.1^{\circ} \Delta 2 \theta\right)$ whereas the modal illite crystallinity value is $0.69^{\circ} \Delta 2 \theta$, typical values of a high diagenetic zone (Merriman and Frey, 1999).

The percent of illitic layers in I/S mixed layers estimated following Moore and Reynolds (1997) suggestions, is in the range of $70-90 \%(R>1$ ordering, Reickeweite number). The high ordering of the mixed layers and the high \% of illitic layer in I/S mixed layers are also consistent with high diagenetic conditions. 


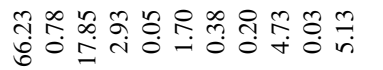

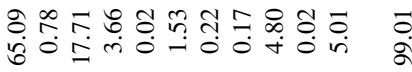

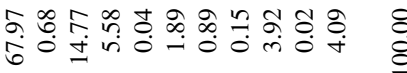

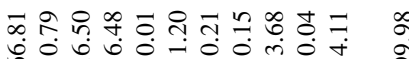

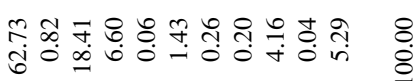

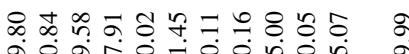

in

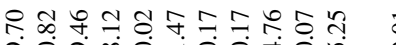

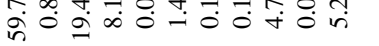

过

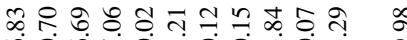

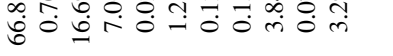

तิ

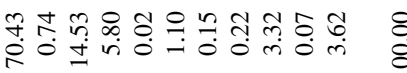

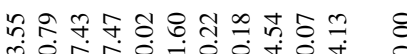

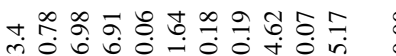

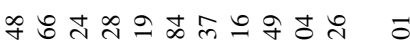

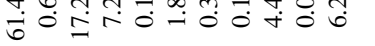

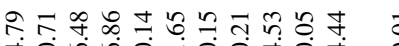

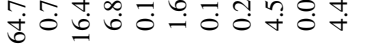

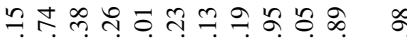

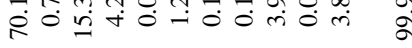

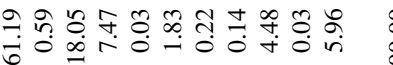

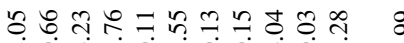

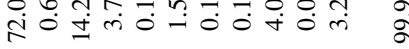

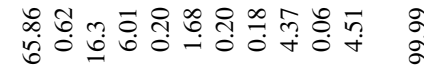

定

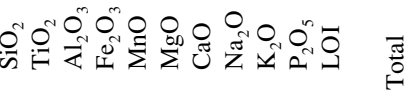

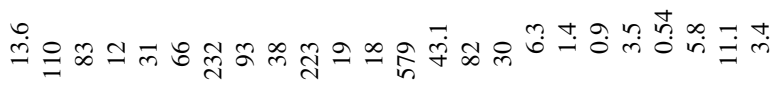

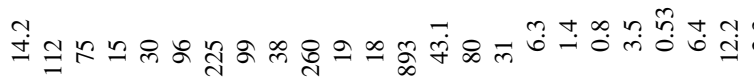

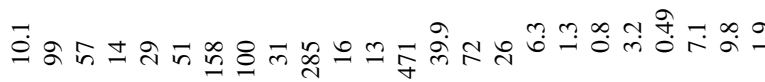

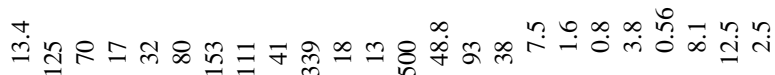

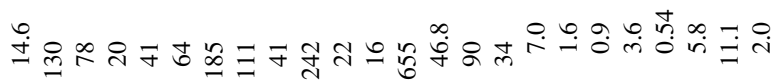

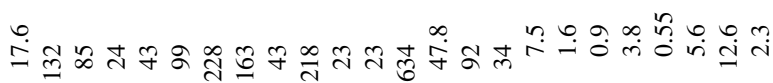

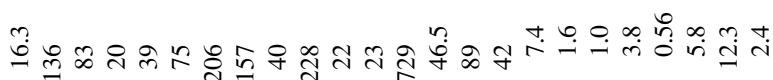

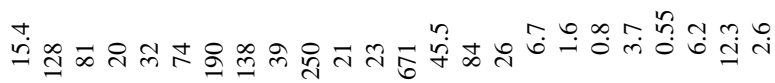

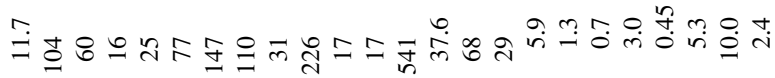

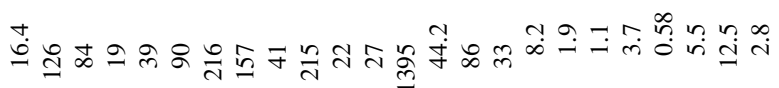

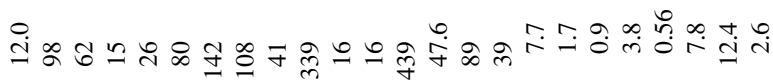

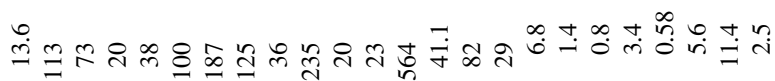

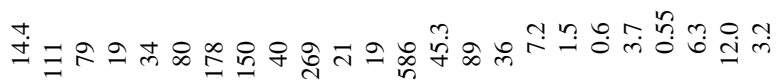

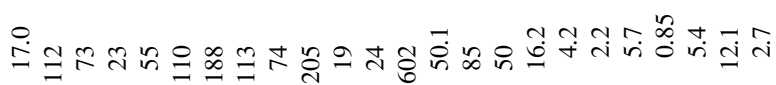

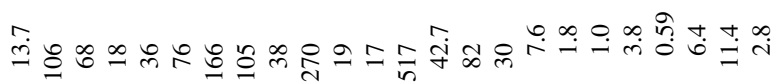

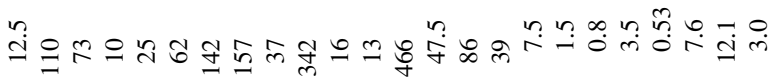

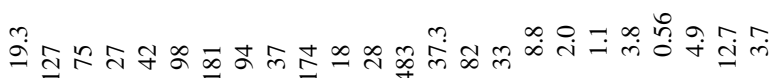

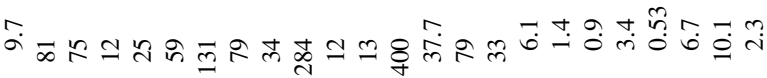

t.

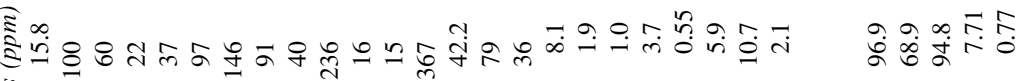
苋

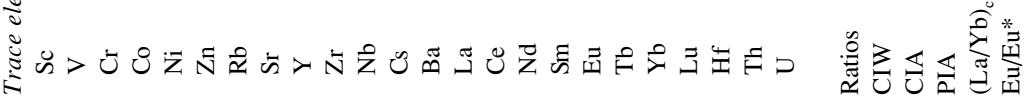




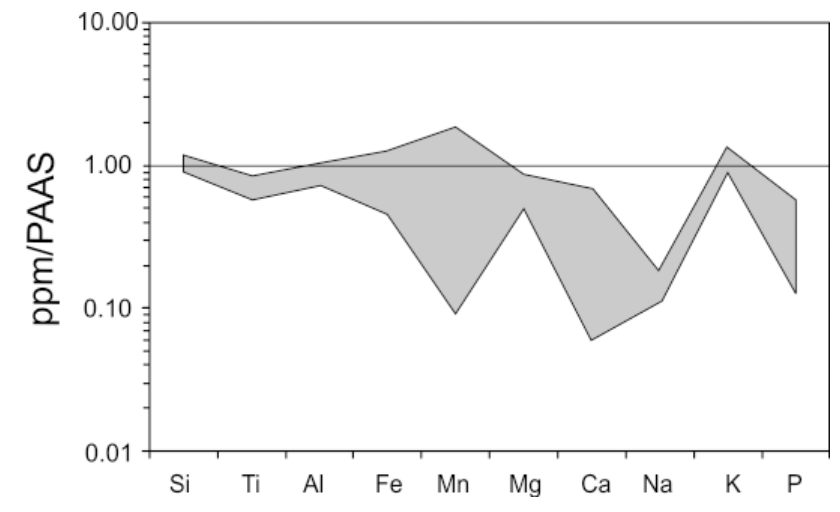

Fig. 4. Major element compositional ranges normalized to the PAAS.

\section{GEOCHEMISTRY}

The elemental concentrations are given in Table 1. The elemental distributions normalized to PAAS are shown in Figs. 4 and 5. REE plots normalized to chondrite (Taylor and McLennan, 1985) are reported in Fig. 7, with the PAAS (Taylor and McLennan, 1985) shown for comparison.

The inter-elemental relationships have been evaluated using R-mode factor analysis. The factors were extracted by Principal Component Analysis (PCA) using the Statistica ${ }^{\circledR}$ package. This operation was performed on the standardized correlation matrix, thus weighting all the variables equally, and allowing us to convert the principal component vectors into factors. The factor loadings arranged as in Table 2 form the factor matrix. The communalities provide an index of the efficiency of the proposed set of factors (Davis, 1986) and the magnitude of the communalities here calculated suggests that most of the original variance is still accounted for our set of factors. Three factors explain $91.2 \%$ of the total variance associated with the chemical database (major and selected trace elements) of the analyzed samples.

\section{Major elements}

The redbeds are characterized by narrow compositional changes for $\mathrm{Si}, \mathrm{Ti}, \mathrm{Al}, \mathrm{Fe}, \mathrm{Mg}$ and $\mathrm{K}$ which have concentrations close to those of PAAS (Fig. 4). Ca, $\mathrm{Na}$, and $\mathrm{P}$ are strongly depleted relatively to PAAS and $\mathrm{Ca}$ shows a high variability in concentration ranging from 0.10 to 0.89 wt $\%$. Mn shows the highest relative dispersion in abundance, ranging from 0.01 to $0.20 \mathrm{wt} \%$ and the element is, in most of the samples, well below the PAAS value ( $0.11 \mathrm{wt} \%)$. The Mn depletion may be due to a sum of effects likely including source-area composition and redox chemistry of the element promoting $\mathrm{Mn}$ solubility as $\mathrm{Mn}^{2+}$ under surface conditions.

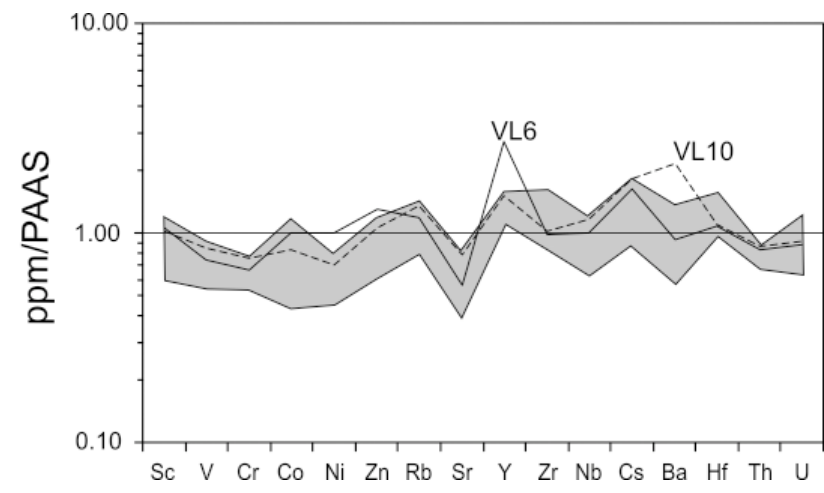

Fig. 5. Trace element compositional ranges normalized to the PAAS. Outlayer samples showing anomalous $Y$ (VL6) and Ba (VL10) contents are shown separately.

$\mathrm{Al}_{2} \mathrm{O}_{3}, \mathrm{Fe}_{2} \mathrm{O}_{3}$, and $\mathrm{K}_{2} \mathrm{O}$ have high positive weights in the first factor obtained (53.2\% of the total variance) whereas $\mathrm{SiO}_{2}$ has a high negative weight. In pelites $\mathrm{Al}_{2} \mathrm{O}_{3}$ monitors clays (Crichton and Condie, 1993) and this factor may thus account for the competition between micalike clay minerals and quartz. In the second factor $(22.7 \%$ of the total variance) $\mathrm{TiO}_{2}$ and $\mathrm{MnO}$ and $\mathrm{TiO}_{2}$ and $\mathrm{MgO}$ have negative weights whereas $\mathrm{MnO}$ and $\mathrm{MgO}$ have a positive weight. This factor could account for the competition between cations in the structure of chlorite and possibly also in the structure of 2:1 clay minerals (illite, smectite).

Large ion lithophile trace elements (LILE): Rb, Cs, Ba, $\mathrm{Sr}$

$\mathrm{Sr}$, similarly to $\mathrm{Ca}$, is depleted relatively to PAAS. $\mathrm{Rb}, \mathrm{Ba}$, and $\mathrm{Cs}$, similarly to $\mathrm{K}$, have abundances close to those of PAAS (Fig. 5). Sample VL 10 has the highest Ba content (1395 ppm) well above the PAAS content (650 $\mathrm{ppm})$. Furthermore $\mathrm{Rb}$ and $\mathrm{Cs}$, which behave similarly to $\mathrm{K}$, have high positive weights in the first factor suggesting that these elements are mostly controlled by the micalike clay minerals.

High field strength trace elements (HFSE): $Y, \mathrm{Zr}, \mathrm{Nb}, \mathrm{Hf}$, REE, Th, $U$

HFSE have concentrations very similar to those of PAAS, although the intermediate rare earth elements (MREE) are enriched relative to the standard shale (Fig. 5).

The chondrite normalized REE patterns (Fig. 6) have a PAAS-like shape characterized by LREE/HREE fractionation (average $\left.(\mathrm{La} / \mathrm{Yb})_{\mathrm{ch}}=8.08 \pm 0.76\right)$ and negative Eu-anomaly (average $\mathrm{Eu} / \mathrm{Eu}^{*}=0.73 \pm 0.04$ ). The average $(\mathrm{La} / \mathrm{Yb})_{\mathrm{ch}}$ ratio is lower than the $(\mathrm{La} / \mathrm{Yb})_{\mathrm{ch}}$ of PAAS (9.2), whereas the Eu-anomaly is higher ( $\mathrm{Eu} /$ $\mathrm{Eu}_{\text {PAAS }}^{*}=0.66$ ). Within this suite of samples VL6 is an 
Table 2. $R$-mode Factor analysis: weights of the variables in the extracted factors. Variables having weight less than 0.600 are omitted.

\begin{tabular}{lccc}
\hline & $\mathrm{F} 1$ & $\mathrm{~F} 2$ & $\mathrm{~F} 3$ \\
\hline $\mathrm{SiO}_{2}$ & -0.96 & & \\
$\mathrm{TiO}_{2}$ & & -0.83 & \\
$\mathrm{Al}_{2} \mathrm{O}_{3}$ & 0.90 & & \\
$\mathrm{Fe}_{2} \mathrm{O}_{3}$ & 0.65 & & \\
$\mathrm{MnO}$ & & 0.81 & \\
$\mathrm{MgO}$ & & 0.61 & \\
$\mathrm{~K}_{2} \mathrm{O}$ & 0.77 & & \\
$\mathrm{Sc}$ & 0.91 & & \\
$\mathrm{~V}$ & 0.79 & & \\
$\mathrm{Cr}$ & 0.68 & & \\
$\mathrm{Co}$ & 0.76 & & \\
$\mathrm{Ni}$ & 0.82 & & \\
$\mathrm{Zn}$ & 0.65 & & \\
$\mathrm{Rb}$ & 0.76 & & \\
$\mathrm{Cs}$ & 0.87 & & \\
$\mathrm{Zr}$ & -0.71 & & \\
$\mathrm{Hf}$ & -0.67 & & \\
$\mathrm{Nb}$ & 0.85 & & \\
$\mathrm{Th}$ & 0.64 & & \\
$\mathrm{La}$ & & & 0.84 \\
$\mathrm{Eu}$ & & 0.69 & \\
$\mathrm{Yb}$ & & & 0.61 \\
$\mathrm{Y}$ & & & 0.61 \\
$\mathrm{Var} . \%$ & 53.2 & 22.7 & 15.3 \\
\hline
\end{tabular}

outlier having very low $(\mathrm{La} / \mathrm{Yb})_{\mathrm{ch}}(5.94)$ and low Euanomaly $\left(\mathrm{Eu} / \mathrm{Eu}^{*}=0.83\right)$ also coupled to the highest $\mathrm{Y}$ concentration.

In the first factor obtained by factor analysis $\mathrm{Zr}$ and $\mathrm{Hf}$ have negative weights, like silica, whereas $\mathrm{Th}$ and $\mathrm{Nb}$ have positive weights. $\mathrm{Zr}$ and $\mathrm{Hf}$ in sediments are controlled by zircon, and due to a combination of resistance to weathering and high specific gravity, this mineral suffers a sorting related fractionation which, in turn, means that $\mathrm{Zr}$ and $\mathrm{Hf}$ are most affected by gravitative fractionation (e.g., Taylor and McLennan, 1985). In the contrast $\mathrm{Th}$ and $\mathrm{Nb}$, which in clastic sediments are usually hosted by resistate minerals (apatite and Ti-oxides) which follow the fate of the clay-sized component, are not seriously affected by sorting-related fractionation.

Eu has significant positive weights in the second factor. It is well known that $\mathrm{Eu}$, due to its different redox chemistry, and differently from the remaining REE's, is concentrated in plagioclase. The weight of the element in this factor may thus indicate that most of the Eu released during plagioclase dissolution could have been trapped by clay minerals by adsorption phenomena, as a mechanism which has proposed, on the basis of mass balance considerations, for fine grained sediments (Mongelli, G. et al., 1996).

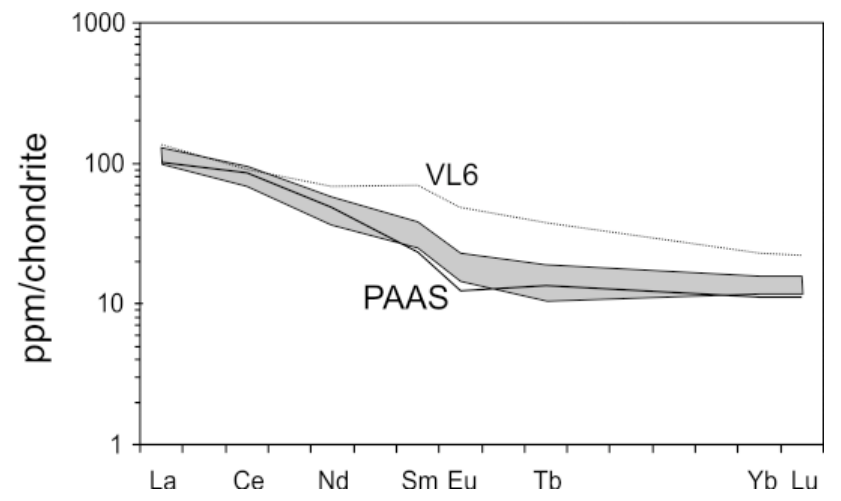

Fig. 6. Rare earth element compositional ranges, chondritenormalized (Taylor and McLennan, 1985). The plot of the Post Archean Australian Shales is shown for comparison. Sample VL6, showing higher content in MREE and HREE is shown separately.

$\mathrm{La}, \mathrm{Yb}$, and $\mathrm{Y}$, which behave like HREE, have positive weights in the third factor $(15.3 \%$ of the total variance). The lack of correlation with $\mathrm{Al}_{2} \mathrm{O}_{3}$, is consistent with the observation that in pelites these elements are generally housed in accessory phases (e.g., Slack and Stevens, 1994; Mongelli, G. et al., 1996). We infer that these elements occur in the sediment mostly as resistate phases, supporting the idea they efficiently record the provenance (e.g., McLennan et al., 1993; Cullers, 1994; Girty et al., 1996; Hassan et al., 1999, Bauluz et al., 2000).

Transition trace elements (TE): $\mathrm{Sc}, \mathrm{V}, \mathrm{Cr}, \mathrm{Co}, \mathrm{Ni}, \mathrm{Zn}$

The concentrations of $\mathrm{Sc}, \mathrm{V}$, and $\mathrm{Zn}$, are close to those of PAAS, whereas $\mathrm{Cr}, \mathrm{Co}$, and $\mathrm{Ni}$ have abundances generally slightly lower than those of PAAS.

All the transition metals appear to covary in the first factor with $\mathrm{Al}_{2} \mathrm{O}_{3}, \mathrm{Fe}_{2} \mathrm{O}_{3}$, and $\mathrm{K}_{2} \mathrm{O}$, suggesting these trace elements are mostly hosted by mica-like clay minerals.

\section{DISCUSSION}

The chemical composition of clastic sediments depends on several factors including source-area composition, palaeoweathering, sorting, and in some cases, burial history. Thus in using terrigenous sediment to monitor provenance one is faced with the nontrivial problem to evaluate and minimize the effects of the other factors.

\section{Source-area weathering}

The most widely used chemical index to determine the degree of source-area weathering is the Chemical Index of Alteration (CIA) proposed by Nesbitt and Young (1982). This index, which works correctly when $\mathrm{Ca}, \mathrm{Na}$, and $\mathrm{K}$ decrease as the intensity of weathering increases (e.g., Duzgoren-Aydin et al., 2002), can be calculated 

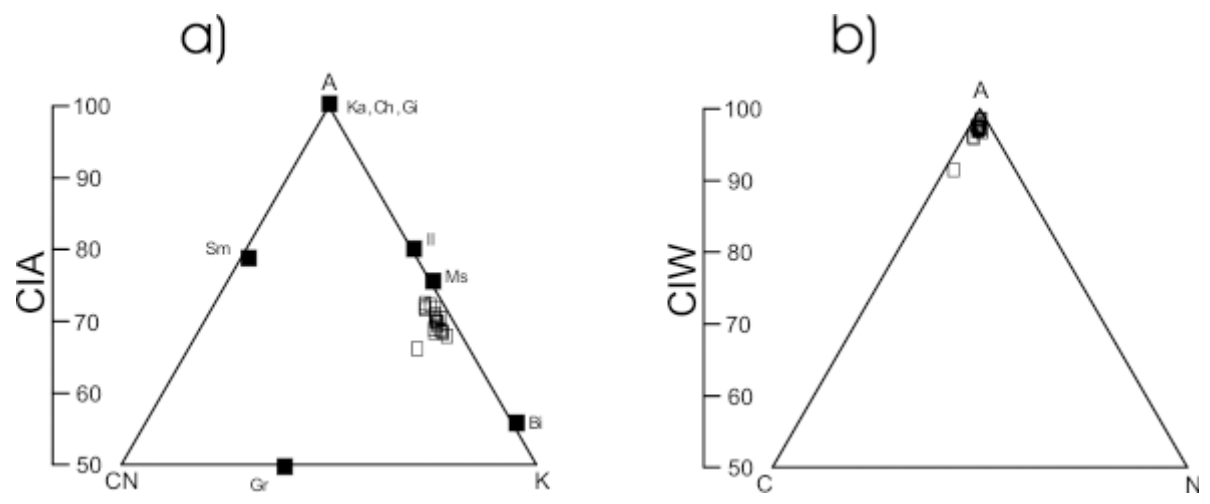

Fig. 7. a) Ternary A-CN-K plot. Legend: Gr, granite; Ms, muscovite; Il, illite; Ka, kaolinite; Ch, chlorite; Gi, gibbsite; Sm, smectite. The samples fall close to the A-K join along a trend indicating $K$ addition during diagenesis. $b) A-C-N$ plot. The samples fall close to the A apex suggesting intense weathering at the source. See text for more details.

using molecular proportion:

$$
\mathrm{CIA}=\left[\mathrm{Al}_{2} \mathrm{O}_{3} /\left(\mathrm{Al}_{2} \mathrm{O}_{3}+\mathrm{CaO} *+\mathrm{Na}_{2} \mathrm{O}+\mathrm{K}_{2} \mathrm{O}\right)\right] \times 100
$$

where $\mathrm{CaO}^{*}$ is the amount of $\mathrm{CaO}$ incorporated in the silicate fraction only. In general, CIA values in Phanerozoic shales ranging from 70 to 75 reflect muscovite, illite and smectite compositions, and indicate a moderately weathered source, whereas CIA values close to 100 are due to more intense weathering which produces residual clays enriched in kaolinite and $\mathrm{Al}$ oxi-hydroxides.

The CIA values of analyzed redbeds are very low (6673 , average $=69.9 \pm 1.7)$ and in the A-CN-K triangular diagram the samples plot in a tight group on the A-K join, and close to the muscovite point (Fig. 7a), suggestive of $\mathrm{K}$-enrichment during diagenesis, according to the mineralogical investigation. Since the CIA index is not sensitive to the weathering degree when $\mathrm{K}$ reintroduction occurs in the system, as in the present case, alternative indices can be used to monitor paleo-weathering at the source. Harnois (1988) proposed the CIW index (Chemical Index of Weathering) which is not sensitive to postdepositional $\mathrm{K}$-enrichments and, similary to the CIA, is a molecular immobile/mobile ratio based on the assumption that $\mathrm{Al}$ remains in the system and accumulates in the residue while $\mathrm{Ca}$ and $\mathrm{Na}$ are leached away:

$$
\mathrm{CIW}=\left[\mathrm{Al}_{2} \mathrm{O}_{3} /\left(\mathrm{Al}_{2} \mathrm{O}_{3}+\mathrm{CaO} *+\mathrm{Na}_{2} \mathrm{O}\right)\right] \times 100
$$

where $\mathrm{CaO}^{*}$ is the amount of $\mathrm{CaO}$ incorporated in the silicate fraction only. Phanerozoic shales have CIW values close to 85 and higher values are indicative of intense weathering. The redbeds, with the exception of the sample VL17, show very uniform CIW values (95-98, average $=97.1 \pm 0.65)$ and in the A-C-N diagram form a tight array close to the A apex (Fig. 7b) suggestive of intense weathering in steady-state conditions where ma- terial removal rate matches the production of mineralogically uniform weathering products generated in the upper zone of soil development. Sample VL17 has a slightly lower CIW index (91) suggestive of less intense weathering at the source.

The degree of the chemical weathering can also be estimated using the Plagioclase Index of Alteration (Fedo et al., 1995); in molecular proportions:

$\mathrm{PIA}=\left[\left(\mathrm{Al}_{2} \mathrm{O}_{3}-\mathrm{K}_{2} \mathrm{O}\right) /\left(\mathrm{Al}_{2} \mathrm{O}_{3}+\mathrm{CaO} *+\mathrm{Na}_{2} \mathrm{O}-\mathrm{K}_{2} \mathrm{O}\right)\right] \times 100$

where $\mathrm{CaO}^{*}$ is the $\mathrm{CaO}$ residing only in the silicate fraction. Unweathered plagioclase has PIA value of 50 whereas the PAAS has PIA value of 79 . The redbeds, with the exception of the sample VL17 (PIA = 86), show very high PIA values $(93-97$, average $=95.3 \pm 1.08)$ indicating that most of the plagioclase has been converted to clay minerals. This, in turn, accords with data obtained using the CIW index, and indicates intense weathering at the source area.

Although the REE are quantitatively transferred from the source to the sediment (e.g., McLennan et al., 1993), intense weathering produces LREE/HREE fractionation (e.g., Mongelli, 1998), possibly due to preferential HREE retention in solution (e.g., Cantrell and Byrne, 1987). For instance carbonate complexes show an increase in stability with increasing atomic number and a preferential retention of HREE in solution as carbonate ions may cause an increase in the $(\mathrm{La} / \mathrm{Yb})_{\text {ch }}$ and slight alkaline conditions may also favour a preferential LREE retention via adsorption onto particle surfaces (Sholkovitz, 1995). This in shales and mudstones may be recognized by both higher values of the $(\mathrm{La} / \mathrm{Yb})_{\mathrm{ch}}$ ratio relatively to the $(\mathrm{La} / \mathrm{Yb})_{\mathrm{ch}}$ of the PAAS and the UCC and significant correlationships between this ratio and the weathering indices (Mongelli, 2004). In this case the $(\mathrm{La} / \mathrm{Yb})_{\mathrm{ch}}$ index (average $=8.08 \pm$ $0.76)$ is lower than the $(\mathrm{La} / \mathrm{Yb})_{\mathrm{ch}}$ of the PAAS (9.2) and it 


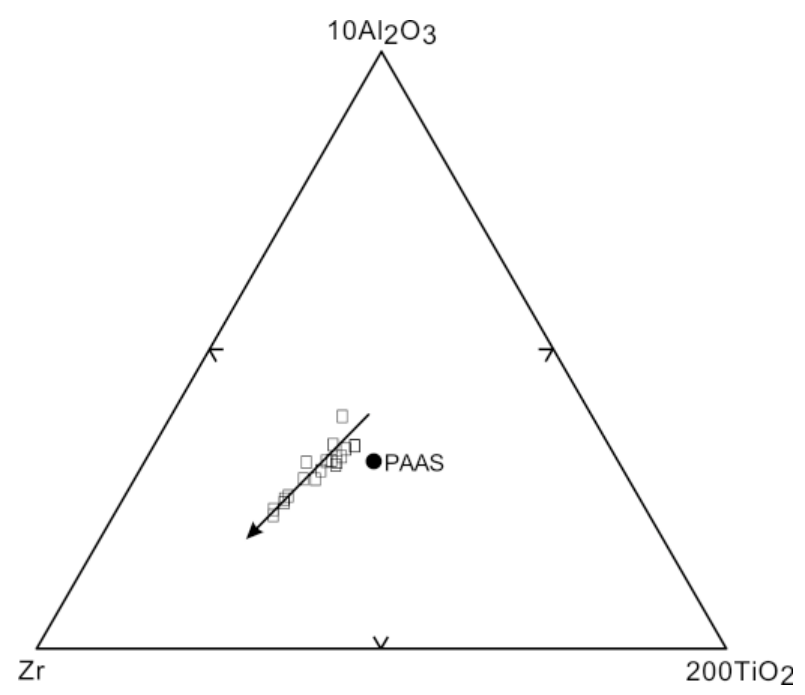

Fig. 8. Ternary $10 \mathrm{Al}_{2} \mathrm{O}_{3}-200 \mathrm{TiO} \mathrm{O}_{2} \mathrm{Zr}$ plot showing possible sorting effects. See text for more details.

is not correlated with the weathering indices (CIW-(La/ $\mathrm{Yb})_{\mathrm{ch}}, \mathrm{r}=0.06$; PIA- $\left.(\mathrm{La} / \mathrm{Yb})_{\mathrm{ch}}, \mathrm{r}=0.09\right)$.

The lack of evidence of intense paleoweathering at the source depicted by the LREE/HREE fractionation is inconsistent with the results obtained using the weathering indices (CIW and PIA). Both CIW and PIA indices are strongly controlled by the amount of plagioclase in the rock, and their paucity in the redbeds could be also record a recycling effect which may especially involve the siliciclastic metasediments of the basement.

\section{Sorting and recycling}

It is well known that transport and deposition of clastic sediments involves mechanical sorting. Its effect on the chemical composition of terrigeneous sediments is important and may affect the distribution of paleoweathering and provenance proxies (Bauluz et al., 2000; Le Pera et al., 2000). The distribution of the chemical components within a suite is mainly determined by the mechanical properties of the host minerals. The process basically fractionates $\mathrm{Al}_{2} \mathrm{O}_{3}$ (clay minerals) from $\mathrm{SiO}_{2}$ (quartz and feldspars). Sorting also fractionates $\mathrm{TiO}_{2}$, mostly present in clay minerals and Ti-oxides, from $\mathrm{Zr}$, present in zircon, and sorted with quartz. However, the variable content of inert elements in mudstone is mostly due to the weathering degree, which affects parent rocks. Ternary plots based on $\mathrm{Al}_{2} \mathrm{O}_{3}, \mathrm{TiO}_{2}$, and $\mathrm{Zr}$ eliminate the weathering effects and may illustrate the presence of sorting-related fractionations which are recognizable by simple mixing trends on a ternary $\mathrm{Al}_{2} \mathrm{O}_{3}-\mathrm{TiO}_{2}-\mathrm{Zr}$ diagram (Garcia et al., 1991). In our case a mixing trend, mostly characterized by changes in the $\mathrm{Al}_{2} \mathrm{O}_{3} / \mathrm{Zr}$ ratio, which could be due to a recycling effect, is clearly envisaged

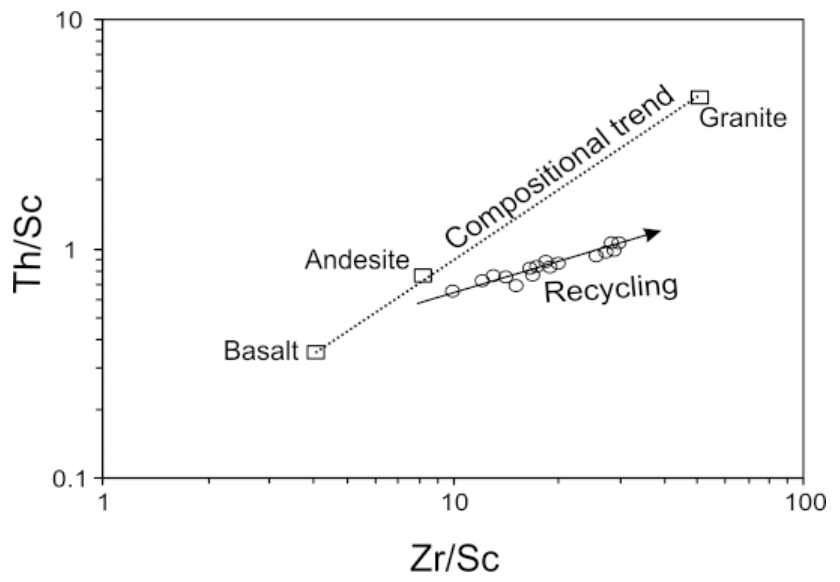

Fig. 9. Th/Sc vs. Zr/Sc plot. Samples depart from the compositional trend indicating zircon addition suggestive of a recycling effect.

(Fig. 8). Zircon, and thus $\mathrm{Zr}$ enrichment during sorting, can also be evaluated when the $\mathrm{Zr} / \mathrm{Sc}$ ratio, a useful index of sediment recycling (e.g., Hassan et al., 2000), is plotted against the $\mathrm{Th} / \mathrm{Sc}$ ratio, an indicator of chemical differentiation (McLennan et al., 1993). The redbeds are not clustered along the primary compositional trend but fall along a trend involving zircon addition (Fig. 9) and thus sediment recycling, consistent with the $\mathrm{Al}_{2} \mathrm{O}_{3}-\mathrm{TiO}_{2}$ $\mathrm{Zr}$ diagram. In addition recycling could significantly affect the weathering indices which likely monitor a cumulative effect including a first cycle of weathering at the source which produced the siliciclastic metasediments of the basement.

It is interesting to observe that the Late TriassicEarliest Jurassic was the time of rifting between Gondwana and Laurasia; initiation of ocean basin formations, rifts and microplates in the western Tethys region and rapid northward drift of the Cimmerian continent, by active seafloor spreading within the Neotethys Ocean (Sengör, 1984), occurred during this time. In the early-late Jurassic time the carbonate sedimentation predominated along all Neotethyan margins (Dercourt et al., 1993; Fourcade et al., 1996); shallow platform grainstones to argillaceous deeper-water carbonates accumulated on the passive margin shelves of the western Neotethys. In the Calabrian-Peloritani Arc indeed the mudstones evolve from continental-transitional redbeds to slope and deep-marine carbonate/clastic sequences (Zuffa et al., 1980).

The late Triassic (Norian supersequence) corresponds with a low first-order sea level stand and a time of high continental emergence; the Early Jurassic (PliensbachianToarcian supersequence) was the time of the initiation of the first-order sea level rise in the mid-Mesozoic (Golonka, 2000, 2002). The Early Jurassic was generally 


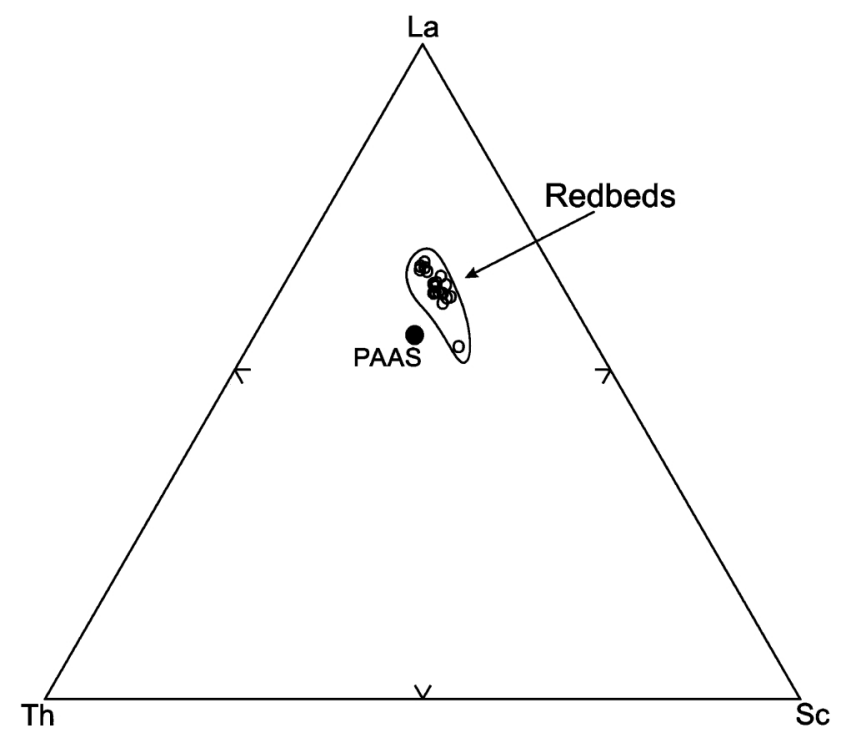

Fig. 10. La-Th-Sc plot. The redbeds fall in a region close to the PAAS point that rules out mafic supply.

marked by a transgressive trend that would continue throughout the entire Jurassic. The transition from icehouse to greenhouse conditions continued in this time (Frakes et al., 1992); greenhouse conditions prevailed with a warm, humid environment, and moderate temperatures into high latitudes, generally arid continental interiors, and no evidence of significant continental glaciation (Golonka, 2000, 2002).

The chemical weathering of such rocks under hot, episodically humid climate with a prolonged dry season, would produce illitization of silicate minerals, oxidation of iron and concentration of quartz in thick soil profiles, that were later denudated by fluvial erosion, producing relatively mature, quartz-rich red deposits. Moreover, palaeocurrent analysis clearly indicates that terrigenous clastics derived from rapid erosion of reliefs located to the N, NW and W of the present-day outcrops of the Calabria-Peloritani Arc realms.

The wet-humid conditions favored the formation of stream channels that eroded the soil profiles, whereas the dry season favoured the sedimentation; successively a new wet-humid conditions causes the erosion of the sediments formed before. The alternation in the early Jurassic time of these two different climatic conditions favoured the recycling process affecting the studied sediments as showed in the $\mathrm{Al}_{2} \mathrm{O}_{3}-\mathrm{Zr}-\mathrm{TiO}_{2}$ and $\mathrm{Th} / \mathrm{Sc}$ vs. $\mathrm{Zr} / \mathrm{Sc}$ diagrams.

\section{Provenance}

It is generally accepted that among trace elements HFSE, especially REE and Th, and some transition elements, including $\mathrm{Sc}$ and $\mathrm{Cr}$, are useful to constrain the

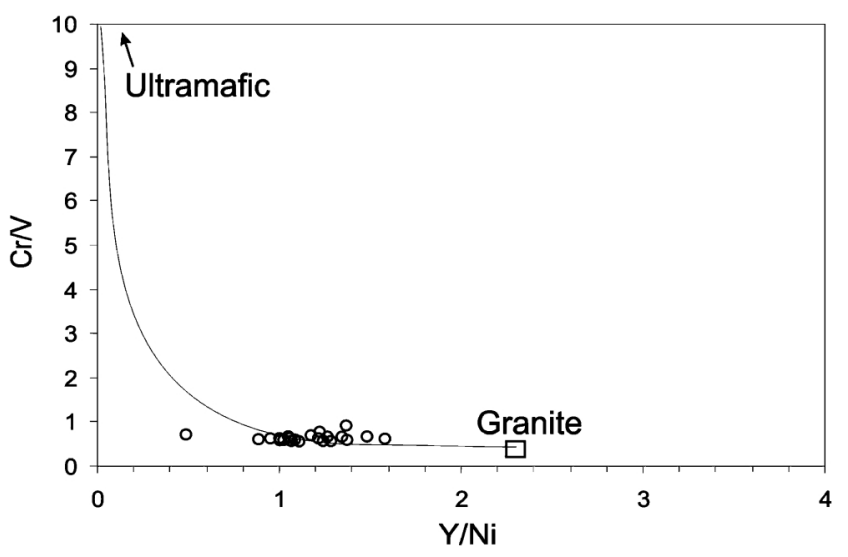

Fig. 11. Cr/V vs. Y/Ni diagram. Curve model mixing between granite and ultramafic end-members. Ultramafic sources have very low $\mathrm{Y} / \mathrm{Ni}$ and high $\mathrm{Cr} / \mathrm{V}$ ratio. The samples have $\mathrm{Y} / \mathrm{Ni}$ and $\mathrm{Cr} / \mathrm{V}$ ratios which exclude mafic supply.

average provenance composition (e.g., Taylor and McLennan, 1985; Fedo et al., 1996; Cullers and Berendsen, 1998). In our case, although we may assume that the metasediments of the Paleozoic basement were a first order source we have to test if other lithologies occurring in the basement, including mafic metavolcanic, represented an additional provenance terrane to the redbeds.

A minor supply from mafic metavolcanic rocks cannot be excluded since the Eu anomaly, which is retained as the more conservative provenance proxy (e.g., McLennan et al., 1993; Mongelli et al., 1998; Cullers, 2000 ), is slightly higher (average $\mathrm{Eu} / \mathrm{Eu}^{*}=0.73 \pm 0.04$ ) than the PAAS value $\left(\mathrm{Eu} / \mathrm{Eu}^{*}=0.66\right)$. It is important to observe that, although the precise effects of recycling on REE distribution are uncertain, it could be expected that $\mathrm{Eu} / \mathrm{Eu}^{*}$ should increase, as more feldspar is destroyed in a second weathering cycle (Hassan et al., 1999). On this basis we may state that the average $\mathrm{Eu} / \mathrm{Eu}^{*}$ of the redbeds, slightly higher than that of the PAAS, could likely monitor supply of low $\mathrm{Eu} / \mathrm{Eu}^{*}$ mafic detritus which compensated for the recycling effect by reducing $\mathrm{Eu} / \mathrm{Eu}$ *. In our case, however, the results of the Principal Component Analysis, as previously stated, suggest that most of the $\mathrm{Eu}$ released during the dissolution of feldspar should be retained by clay minerals thus minimizing the recyclinginduced increase of the Eu-anomaly. This may imply that the recycling effect on the Eu-anomaly was minor and, in turn, that the low $\mathrm{Eu} / \mathrm{Eu}^{*}$ mafic detritus supply was also minor although not negligible.

The limited importance of a mafic supply is confirmed also by other provenance proxies including the $\mathrm{La}-\mathrm{Th}-\mathrm{Sc}$ plot and the $\mathrm{Cr} / \mathrm{V}$ and $\mathrm{Y} / \mathrm{Ni}$ ratios. The La-Th-Sc plot has been used to discriminate sediments from felsic sources 
to progressively more mafic sources (Bhatia and Crook, 1986; Cullers, 1994). The redbeds fall in a region close to the PAAS point (Fig. 10) that clearly rules out a predominantly mafic source; a significant mafic-ultramafic supply is excluded also on the basis of the mixing curve between granite and a mafic-ultramafic end-member (Fig. 11) in the Y/Ni vs. Cr/V diagram.

\section{Burial history}

The reaction in which smectite is a reactant and illite a product, recognized to occur over a predictable range of depth in mudstones, is here used as a comparative "geothermometer" jointly with the illite crystallinity value (IC), expressed as Kübler Index (KI). Usually, the smectite-to-illite reaction concerns the diagenetic range, whereas the illite "crystallinity" improvement and the mica polytype $2 \mathrm{M}_{1}$ percentage variation mainly applies to the early stages of metamorphism, i.e., very low (anchizone) and low (epizone) grades (Chamley, 1995).

In estimating temperatures from clay minerals evolution in the Longi succession, the basin maturity chart, showing correlation of reaction progress in the smectiteI/S-illite series and IC with temperature, proposed by Merriman and Frey (1999) was adopted, since it refers to a large variety of geological settings and is therefore more representative of the evolution of such minerals through time. So by integrating data relative to the percentage of illitic layers in I/S mixed layers with illite crystallinity values, expressed as Kübler Index (KI), the temperature experienced by the Longi Units following the Basin Maturity Chart (BMC) of Merriman and Frey (1999), can be estimated as in the range of $100-150^{\circ} \mathrm{C}$.

Starting from the temperature estimates by clay-minerals-based geothermometers and considering an average geothermal gradient of $20 / 30^{\circ} \mathrm{C}$ (Mongelli, F. et al., 1996), a diagenetic/tectonic evolution corresponding to about 4$5 \mathrm{~km}$ of lithostatic/tectonic loading can be hypothezised for the Longi succession.

\section{CONCLUSIONS}

Geochemistry and mineralogy of Mesozoic continental redbeds from the typical Longi stratigraphic section of the Peloritani Mountains suggest a complex history. The redbeds have concentrations very similar to those of the PAAS for $\mathrm{Si}, \mathrm{Ti}, \mathrm{Al}, \mathrm{Fe}, \mathrm{Mg}, \mathrm{K}, \mathrm{Rb}, \mathrm{Ba}, \mathrm{Cs}$, HFSE, and transition metals whereas $\mathrm{Ca}, \mathrm{Na}, \mathrm{P}$, and $\mathrm{Sr}$ are strongly depleted.

The mineralogical assemblage, dominated by the occurrence of illite and illite/smectite mixed layers, coupled to the CIA index and to the A-CN-K plot, indicates that post-depositional K-enrichments affected the bulk composition of the rock. CIW and PIA indices suggest that weathering at the source was intense and occurred in steady-state conditions. Since CIW and PIA indices are strongly controlled by the amount of plagioclase in the rock, their paucity in the redbeds likely record a recycling effect which may especially involve the siliciclastic metasedimentary basement rocks.

The distribution of $\mathrm{Al}_{2} \mathrm{O}_{3}, \mathrm{TiO}_{2}$, and $\mathrm{Zr}$ and the values of the $\mathrm{Zr} / \mathrm{Sc}$ and $\mathrm{Th} / \mathrm{Sc}$ ratios further support this idea. In the $\mathrm{Zr} / \mathrm{Sc}$ vs. the Th/Sc plot the redbeds are not clustered along the primary compositional trend but fall along a trend involving zircon addition and thus sediment recycling. $\mathrm{Zr}$ addition may also account for the observed low $(\mathrm{La} / \mathrm{Yb})_{\mathrm{ch}}$ ratio of the redbeds. In addition, recycling could significantly affect the weathering indices which likely monitor a cumulative effect including a first cycle of weathering at the source which produced the siliciclastic metasediments of the basement. During Early Jurassic weathering likely occurred under hot, episodically humid climate with a prolonged dry season. The wet-humid conditions promoted erosion whereas the dry season favored the sedimentation. Thus, climate alternation favored the recycling process affecting the studied sediments as showed in the $\mathrm{Al}_{2} \mathrm{O}_{3}-\mathrm{Zr}-\mathrm{TiO}_{2}$ and $\mathrm{Th} / \mathrm{Sc}$ vs. $\mathrm{Zr} / \mathrm{Sc}$ diagrams.

Although we may assume that the metasediments of the Paleozoic basement were a first order source lithologies an additional provenance terrane occurring in the basement, including metavolcanic rocks of mafic composition cannot be excluded, since the Eu anomaly, which is retained as the more conservative provenance proxy, is slightly higher than the PAAS value.

Although the precise effects of recycling on REE distribution are uncertain, the $\mathrm{Eu} / \mathrm{Eu}^{*}$ should increase, as more feldspar is destroyed in a second weathering cycle which, in turn, involves that the $\mathrm{Eu} / \mathrm{Eu}^{*}$ ratio of the redbeds could monitor a supply of low $\mathrm{Eu} / \mathrm{Eu} *$ mafic detritus which compensate for the recycling effect by reducing $\mathrm{Eu} / \mathrm{Eu}^{*}$. Statistical analysis (PCA) however suggests that most of the Eu released during the dissolution of feldspar should be retained by clay minerals thus contributing to minimize the recycling induced increase of the Eu-anomaly. This may involve that the recycling effect on the Eu-anomaly was minor and that the low $\mathrm{Eu} /$ $\mathrm{Eu}^{*}$ mafic detritus supply was also minor. The limited importance of a mafic supply is confirmed also by other provenance proxies including the La-Th-Sc plot and the $\mathrm{Cr} / \mathrm{V}$ and $\mathrm{Y} / \mathrm{Ni}$ ratios.

Finally, the estimated temperature experienced by the Longi Units, obtained by coupling data relative to the percentage of illitic layers in I/S mixed layers with the illite crystallinity values, expressed as Kübler Index (KI), is in the range of $100-150^{\circ} \mathrm{C}$. Starting from the temperature estimates by clay-minerals-based geothermometers the diagenetic/tectonic evolution should correspond to a lithostatic/tectonic loading of about $4-5 \mathrm{~km}$. 
Acknowledgments-H. Ishiga, J. Viers, and an anonimous referee reviewed the manuscript and provided many helpful comments.

\section{REFERENCES}

Arnone, G., De Rosa, P. and Masciari, A. (1978) Osservazioni geologiche nella zona di Longi (Monti Peloritani occidentali). Bollettino della Società Geologica Italiana 98, 217-226.

Bauluz, B., Mayayo, M. J., Fernandez-Nieto, C. and Gonzalez Lopez, J. M. (2000) Geochemistry of Precambrian and Paleozoic siliciclastic rocks from the Iberian Range (NE Spain): implications for source-area weathering, sorting, provenace, and tectonic setting. Chemical Geology 168, $135-150$.

Bhatia, M. R. and Crook, K. A. W. (1986) Trace element characteristics of graywackes and tectonic setting discrimination of sedimentary basins. Contributions to Mineralogy and Petrology 92, 181-193.

Bonardi, G., Giunta, G., Liguori, V., Perrone, V., Russo, M. and Zuppetta, A. (1976) Schema geologico dei Monti Peloritani. Bollettino della Società Geologica Italiana 95, 49-74.

Bonardi, G., Cavazza, W., Perrone, V. and Rossi, S. (2001) Calabria-Peloritani terrane and Northern Ionian Sea. Anatomy of an Orogen: The Apennines and Adjacent Mediterranean Basins (Vai, G. B. and Martini, I. P., eds.), 287306, Kluwer Academic Publishers, Dordrecht/Boston/London.

Cantrell, K. J. and Byrne, R. H. (1987) Rare earth element complexation by carbonate and oxalate ions. Geochim. Cosmochim. Acta 51, 597-605.

Chamley, H. (1995) Clay Sedimentology. Springer, Berlin.

Condie, K. C., Lee, D. and Farmer, G. L. (2001) Tectonic setting and provenance of the Neoproterozoic Uinta Mountain and Big Vottonwood groups, northern Utah: constraints from geochemistry, Nd isotopes, and detrital modes. Sedimentary Geology 141-142, 443-464.

Crichton, J. G. and Condie, K. C. (1993) Trace elements as source indicators in cratonic sediments: a case study from the Early Proterozoic Libby Creek Group, southweastern Wyoming. Jour. Geol. 101, 319-332.

Critelli, S. (1999) The interplay of lithospheric flexure and thrust accomodation in forming stratigraphic sequences in the Southern Apennines foreland basin system, Italy. Rendiconti di Scienze Fisiche e Naturali dell'Accademia Nazionale dei Lincei, ser. 9 10, 257-326.

Cullers, R. L. (1994) The controls on the major and trace element variation of shales, siltstones, and sandstones of Pennsylvanian-Permian age from uplifted continental blocks in Colorado to platform sediments in Kansas, USA. Geochim. Cosmochim. Acta 58, 4955-4972.

Cullers, R. L. (2000) The geochemistry of shales, siltstones and sandstones of Pennsylvian-Permian age, Colorado, USA: implications for provenance and metamorphic studies. Lithos 51, 181-203.

Cullers, R. L. and Berendsen, P. (1998) The provenance and chemical variation of sandstones associated with the Mid- continent rift system, U.S.A. European Journal of Mineralogy 10, 987-1002.

Davis, J. C. (1986) Statistics and Data Analysis in Geology. Wiley \& Sons, New York, 646 pp.

de Capoa, P., Guerrera, F., Perrone, V. and Serrano, F. (1997) New biostratigraphic data on the Frazzanò Formation (Longi-Taormina unit): consequences on defining the deformation age of the Calabria-Peloritani arc southern sector. Rivista Italiana di Paleontologia e Stratigrafia 103, 3 , 343-356.

Dercourt, J., Ricou, L. E. and Vrielynck, B. (1993) Atlas Tethys Paleoenvironmental Maps. Gauthier-Villars, Paris, 307 pp., 14 maps, 1 pl.

Duzgoren-Aydin, N. S., Aydin, A. and Malpas, J. (2002) Reassessment of chemical weathering indices: case study on pyroclastic rocks of Hong Kong. Engineering Geology 63, 99-119.

Fedo, C. M., Nesbitt, H. W. and Young, G. M. (1995) Unraveling the effect of potassium metasomatism in sedimentary rocks and paleosols, with implications for paleoweathering conditions and provenance. Geology 23, 921-924.

Fedo, C. M., Eriksson, K. A. and Krogstad, E. J. (1996) Geochemistry of shales from the Archean $(\approx 3.0 \mathrm{Ga})$ Buhwa Greenstone belt, Zimbabwe: Implication for provenance and source area weathering. Geochim. Cosmochim. Acta 60, 1751-1763.

Fourcade, E., Azéma, J., Bassoulet, J.-P., Cecca, F., Dercourt, J., Enay, R. and Guirard, R. (1996) Paleogeography and Paleoenvironment of the Tethyan Realm during the Jurassic Breakup of Pangea. The Oceans Basins and Margin, Vol. 8 The Tethys Ocean (Nairn, A. E. M., Ricou, L.-E., Vrielynck, B. and Dercourt, J., eds.), 191-214, Plenum Press, New York and London.

Frakes, L. A., Francis, J. E. and Syktus, J. I. (1992) Climate Modes of the Phanerozoic: The History of the Earth's Climate over the Past 600 Million Years. Cambridge, Cambridge University Press, $274 \mathrm{pp}$.

Franzini, M., Leoni, L. and Saitta, M. (1972) A simple method to evaluate the matrix effects in X-ray fluorescence analysis. $X$-ray Spectrometry 1, 151-154.

Franzini, M., Leoni, L. and Saitta, M. (1975) Revisione di una metodologia analitica per fluorescenza X basata sulla correzione degli effetti di matrice. Rendiconti Società Italiana di Mineralogia e Petrologia 31, 365-378.

Garcia, D., Coehlo, J. and Perrin, M. (1991) Fractionation between $\mathrm{TiO}_{2}$ and $\mathrm{Zr}$ as a measure of sorting within shale and sandstone series (northern Portugal). European Journal of Mineralogy 3, 401-414.

Girty, G. H., Ridge, D. L. Knaak, C., Johnson, D. and Al-Ryami, R. (1996) Provenance and depositional setting of Paleozoic chert and argillite, Sierra Nevada, California. J. Sedim. Res. 66, 107-118.

Golonka, J. (2000) Cambrian-Neogene Plate Tectonic Maps. Wydawnictwa Uniwersytetu Jagiello_skiego, Kraków, 125 pp.

Golonka, J. (2002) Plate-tectonic maps of the Phanerozoic. Phanerozoic Reef Patterns (Kiessling, W., Flügel, E. and Golonka J., eds.), SEPM (Society for Sedimentary Geology) Special Publication 72, 21-75, Tulsa. 
Harnois, L. (1988) The C.I.W. index: a new chemical index of weathering. Sedimentary Geology 55, 319-322.

Hassan, S., Ishiga, H., Roser, B. P., Dozen, K. and Naka, T. (1999) Geochemistry of Permian Triassic shales in the Salt range, Pakistan: implications for provenance and tectonism at the Gondwana margin. Chemical Geology 168, 293-314.

Kübler, B. (1967) La cristallinitè de l'illite et les zones tout à fait supèrieures du mètamorphisme. Etages Tectoniques, Colloque de Neuchâtel (Kübler, B., eds.), 105-121, Universitè Neuchâtel à la Baconnière. Neuchâtel, Switzerland.

Le Pera, E., Mongelli, G., Morelli, F. and Critelli, S. (2000) Compositional and geochemical signature of provenance in modern sediments from the tyrrhenian continental shelf, Calabria, Italy. Giornale di Geologia 62, 49-67.

Lentini, F. (1975) Le successioni mesozoico-terziarie dell'Unità di Longi (complesso Calabride) nei Peloritani occidentali (Sicilia). Bollettino della Società Geologica Italiana 94, 1477-1503.

Lentini, F. and Vezzani, L. (1975) Le unità meso-cenozoiche della copertura sedimentaria del basamento cristallino peloritano (Sicilia nord-orientale). Bollettino della Società Geologica Italiana 94, 537-554.

Lentini, F., Catalano, S. and Carbone, S. (2000) Carta geologica della provincia di Messina in scala 1:50000. S.E.L.C.A., Firenze.

Leoni, L. and Saitta, M. (1976) X-ray fluorescence analysis of 29 trace elements in rock and mineral standards. Rendiconti Società Italiana di Mineralogia e Petrologia 32, 497-510.

McLennan, S. M., Hemming, D. K. and Hanson, G. N. (1993) Geochimical aproaches to sedimentation, provenance and tectonics. Geol. Soc. Am. Spec. Pap. 284, 21-40.

Merriman, R. J. and Frey, M. (1999) Very low-grade metapelites: mineralogy, microfabric and measuring reaction progress. Low-Grade Metamorphism (Frey, M. and Robonson, D., eds.), 10-58, Blackwell Science, Oxford.

Merriman, R. J. and Peacor, D. R. (1999) Very low grade metapelites: mineralogy, microfabric and measuring reaction progress. Low-Grade Metamorphism (Frey, M. and Robonson, D., eds.), 10-58, Blackwell Science, Oxford.

Messina, A., Russo, S. and Stagno, F. (1996) The cristalline basements of the Calabria-Peloritani Arc. IGCP Project 276, Newsletter, 6, 91-144, Messina.

Mongelli, F., Harabaglia, P., Martinelli, G., Squarci, P. and Zito, G. (1996) Nuove misure di flusso geotermico in Italia meridionale: possibili implicazioni sismotettoniche. Proc. 14th GNGTS, Rome, October 23-25, 1995.

Mongelli, G. (2004) Rare-earth elements in Oligo-Miocenic pelitic sediments from Lagonegro basin, southern Apennines, Italy: implications for provenance and source-area weathering. International Journal of Earth Sciences, 93,
$612-620$

Mongelli, G., Cullers, R. and Muelheisen, S. (1996) Geochemistry of Cenozoic shales from the Varicolori Formation, Southern Apennines, Italy: implications for mineralogical, grain size control and provenance. European Journal of Mineralogy, 8, 733-754.

Mongelli, G., Cullers, R., Dinelli, E. and Rottura, A. (1998) Elemental mobility during the weathering of exposed lower crust: the kinzigitic paragneisses from the Serre, Calabria, Southern Italy. Terra Nova 10, 190-195.

Moore, D. M. and Reynolds, R. C. (1989) X-ray Diffraction and Identification and Analysis of Clay Minerals. Oxford University Press, Oxford.

Nesbitt, H. W. and Young, G. M. (1982) Early Proterozoic climates and plate motions inferred from major element chemistry of lutites. Nature 299, 715-717.

Perrone, V., Martín-Algarra, A., Critelli, S., Decandia, F. A., D’Errico, M., Estevez, A., Iannace, A., Lazzarotto, A., Martín-Martín, M., Martín-Rojas, I., Mazzoli, S., Messina, A., Mongelli, G., Vitale, S. and Zaghloul, N. M. (2005) "Verrucano" and "Pseudoverrucano" in the central-western Mediterranean Alpine chains. Geological Society of London Special Publications (in press).

Pollastro, R. M. (1993) Considerations of the illite-smectite geothermometer in hydrocarbon-bearing rocks of Miocene to Mississippian age. Clays and Clay Minerals 41, 119133.

Scandone, P., Giunta, G. and Liguori, V. (1974) The connection between the Apulia and Sahara Continental Margins in the Southern Apennines and in the Sicily. Memorie della Società Geologica Italiana, II 13, 317-323.

Sengör, A. M. C. (1984) The Cimmeride orogenic system and the tectonics of Eurasia. Geological Society of America Special Paper 195, 1-82.

Sholkovitz, E. R. (1995) The aquatic chemistry of rare earth elementsin rivers and estuaries. Aquat. Geochem. 1, 1-34.

Slack, J. F. and Stevens, B. P. J. (1994) Clastic metasediments of the Early Proterozoic Broken Hill Group, New South Wales, Australia: geochemistry, provenance, and metallogenic significance. Geochim. Cosmochim. Acta $\mathbf{5 8}$, 257-273.

Taylor, S. R. and McLennan, S. M. (1985) The Continental Crust: Its Composition and Evolution. Blackwell, Oxford.

Warr, L. N. and Rice, A. H. N. (1994) Interlaboratory standardization and calibration of clay mineral crystallinity and crystal size data. Journal of Metamorphic Geology 12, 141152.

Zuffa, G. G., Gaudio, W. and Rovito, S. (1980) Detritial mode evolution of the rifted continental-margin Longobucco Sequence (Jurassic), Calabrian Arc, Italy. J. Sediment. Petrol. 50, 51-62. 